\title{
The Environmental Impacts of Kabd Landfill on the Soil and Groundwater in Kuwait: A Case Study
}

\author{
Ahmed R. Al Rashed \\ Department of Earth Science, College of Basic Education, PAAET, Kuwait \\ Email:ahmedbufarsan@gmail.com
}

How to cite this paper: Al Rashed, A.R. (2018) The Environmental Impacts of Kabd Landfill on the Soil and Groundwater in Kuwait: A Case Study. International Journal of Geosciences, 9, 255-271.

https://doi.org/10.4236/ijg.2018.95016

Received: February 6, 2018

Accepted: May 12, 2018

Published: May 15, 2018

Copyright $\odot 2018$ by author and Scientific Research Publishing Inc. This work is licensed under the Creative Commons Attribution International License (CC BY 4.0).

http://creativecommons.org/licenses/by/4.0/

\begin{abstract}
The environmental impacts of the Kabd Landfill on the soil and groundwater in Kuwait were evaluated. Physical and chemical analyses were carried out on thirty pairs of surface, subsurface soil and five groundwater samples. The groundwater samples are collected from boreholes nearby and downstream of the landfill while the soil samples collected along six profiles. The groundwater samples were geochemically analyzed to determine the total dissolved solids, cations, anions and heavy metals, particularly Iron $(\mathrm{Fe})$, Copper $(\mathrm{Cu})$, zinc ( $\mathrm{Zn})$, Cadmium (Cd), Nickel (Ni), Chromium (Cr) and Aluminum (Al), Lithium (Li), Boron (B), Fluoride (F) and Vanadium (V). The soil samples were geochemically analyzed to determine concentration of Cadmium $(\mathrm{Cd})$, Lead $(\mathrm{Pb})$, Nickel $(\mathrm{Ni})$, Iron $(\mathrm{Fe})$, Aluminum $(\mathrm{Al})$ and organics. The results show that the soil and groundwater are contaminated with high TDS, Na, Ca, $\mathrm{Mg}, \mathrm{Cl}, \mathrm{SO}_{4}$ and heavy metals, especially $\mathrm{Ni}, \mathrm{Cd}, \mathrm{Cu}, \mathrm{Al}, \mathrm{V}$ and $\mathrm{F}$. The heavy metal concentrations in both the soil and groundwater samples are compared to the World Health Organization (WHO) standard permissible limits. The results revealed that the $\mathrm{Zn}, \mathrm{Li}, \mathrm{B}$ and Fe metals are below the WHO limits for consumption. The soil lithology, natures of dumping, the depth of quarry and the depth to the groundwater level play roles in leachate generation and groundwater contaminations. Such leachate may be originated from the capillary fringe water, moisture content and rising water table, due to its close level at the bottom of the waste disposal site. The organic strength of the soil was reduced due to waste decomposition and continuous gas flaring. Re-designing of sanitary landfills to prevent leachate from getting to the groundwater and adoption of clean technology for a sustainable land management program for reclamation is recommended.
\end{abstract}

\section{Keywords}

Environmental Impacts, Landfill, Kuwait, Soil, Groundwater 


\section{Introduction}

The state of Kuwait is situated at the northeastern corner of the Arabian Peninsula. It comprises an area of approximately $17,600 \mathrm{~km}^{2}$, with the Geographic Coordinates of $30^{\circ} 20^{\prime} 15^{\prime \prime} \mathrm{N}$ and $47^{\circ} 39^{\prime} 29^{\prime \prime} \mathrm{E}$ (Figure 1 ). The landfill sites are considered as an environmental problem for the urban areas. The impacts of these landfills, are growing especially after the urban expansion opened, where some of landfills became inside the residential areas or near to them (Figure 2). Some of these landfills are closed, others re-opened to receive thousands of tons per day of waste such as Kabd solid wastes landfill. This landfill was introduced in 1999, to fill the remnants of animal shelters and household waste. It was closed in 2001 and remained closed for more than 10 years before reopening to

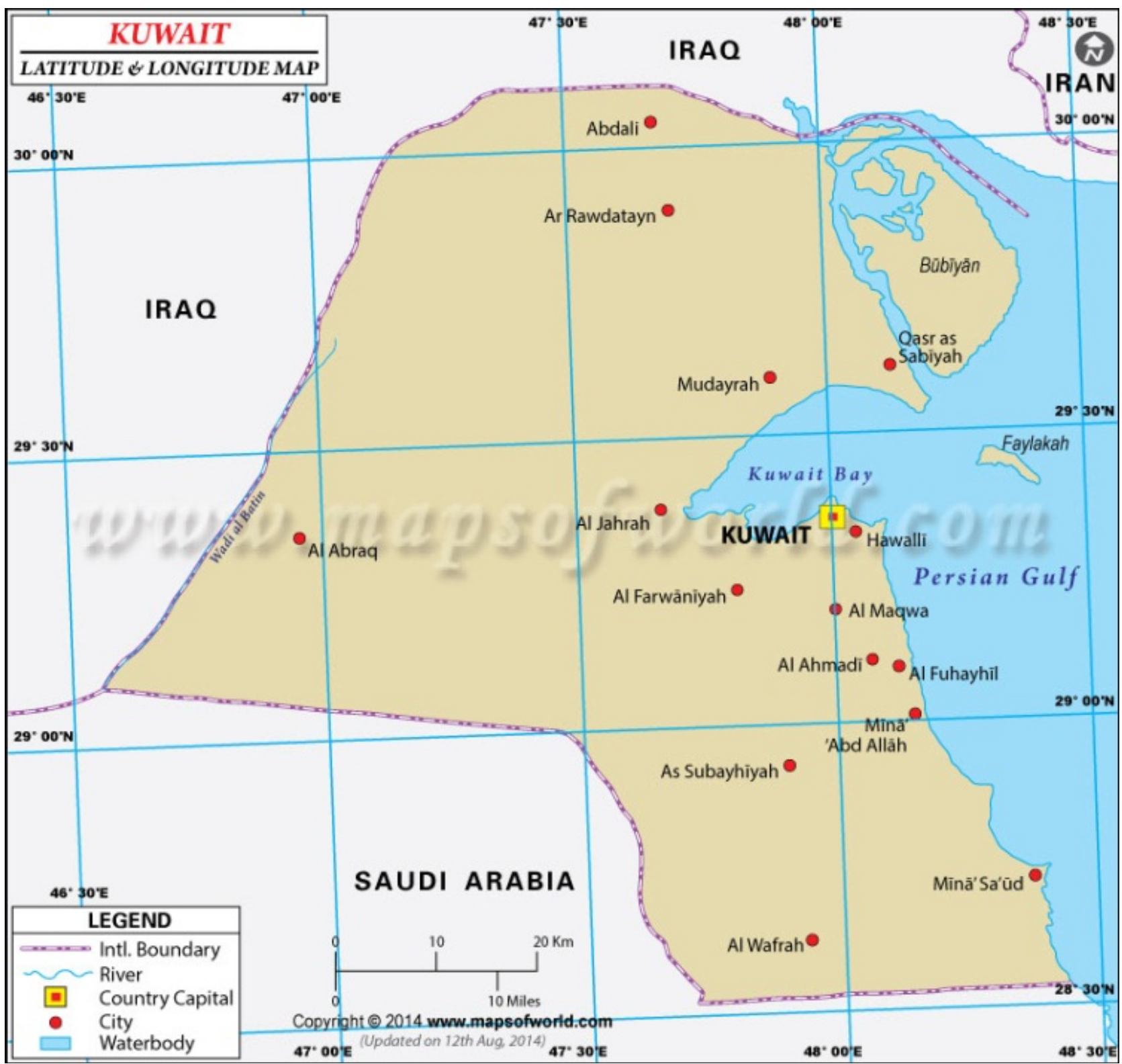

Figure 1. The geographical location of Kuwait and its neighboring countries. https://www.google.com.kw/ 




Figure 2. The landfill sites in the state of Kuwait.

receive again different solid and household wastes.

The closure of the waste-dump does not imply the absence of environmental risks. It might be possible that even when sealed, a landfill might contaminate the soils and groundwater of the area. The water moves down into the ground because of gravity, passing between particles of soil, sand, gravel, or rock until it reaches a depth where the ground is filled, or saturated, with water.

The concentration of waste materials in the landfill site had systematically polluted the soil and groundwater over time [1]. The effect of such pollution as determined from the study declined away from the polluting source. This implied that the contamination of the groundwater was more dependent on the proximity to the dump sites. Smaller dependence has been attributed to the influence of topography, type, state of waste disposal systems and, to some extent, hydrogeology of the area.

Groundwater pollution is mainly due to the process of industrialization and urbanization that has progressively developed over time without any regard for environmental consequences [2]. In recent times, the impact of leachate on groundwater and other water resources has attracted a lot of attention because of 
its overwhelming environmental significance. Leachate migration from wastes sites or landfills and the release of pollutants from sediments (under certain conditions) pose a high risk to the groundwater resources if not adequately managed [3]. Groundwater protection is a major environmental issue. Open dumps are the oldest and most common way of disposing solid wastes, and although in recent years thousands of them have been closed, many are still being used [4]. The frequently used municipal solid waste disposal methods include: composting, sanitary landfill, and pyrolysis, reuse recovery and recycling [5].

[6] stated that excessive accumulation of heavy metals in agricultural soils through waste water irrigation, may not only result in soil contamination, but also lead to elevated heavy metal uptake by crops, and thus affect food quality and safety [7]. The pollution load index values indicated that the wastewater-irrigated soils were moderately enriched with $\mathrm{Cr}, \mathrm{Cu}, \mathrm{Ni}, \mathrm{Pb}$ and $\mathrm{Zn}$, and strongly enriched with $\mathrm{Cd}$. Heavy metals are a potential human health concern when concentrations are at high levels in soils. Breathing dust coming from soil may also pose a health risk. Metals of concern are arsenic (As), cadmium (Cd), chromium $(\mathrm{Cr})$, copper $(\mathrm{Cu})$, lead $(\mathrm{Pb})$, nickel $(\mathrm{Ni})$, selenium $(\mathrm{Se})$, and zinc (Zn).

The aims of this are to evaluate the impacts of Kabd solid waste landfill, that possible generates a permanent long-term source of pollution to the soil horizon and the groundwater, however to detect the role of groundwater flow direction on the movement of landfill pollutants and to develop appropriate scientific solutions to reduce the landfill impacts.

\section{Materials and Methodology}

The materials used in the present study include groundwater, surface and subsurface soil samples collected from the landfill site and neighboring areas. Location of the water wells and soil samples are shown in Figure 3.

The samples were collected from Jan to June 2016 as follows:

1) Five groundwater samples from already drilled water wells, down-stream of the Landfill.

2) Thirty pairs of surface and subsurface soil samples along six transect. The subsurface samples are collected by digging a hole of $30 \mathrm{~cm}$ depth.

The field observations, related to the landfill waste types, waste sorting and burial methods, have been reported for the subsequent interpretation process. The soil samples are subjected to geochemical analysis in the INCO-LABS (KSCC) to determine the Cadmium, Lead, Nickel, Iron, Aluminum and Organic concentrations using the APHA3120 Method. The groundwater samples are geochemically analyzed to determine the TDS, Chloride, Sulfate, Nitrate, Calcium, Magnesium, Sodium, Potassium, Iron, Copper, Nickel, Zinc, Aluminum, Lithium, Boron and Fluoride concentrations. Processing and illustration of the results of the geochemical analyses data are done using specialized graphs and distribution maps utilizing up-to-date specialized softwares. 


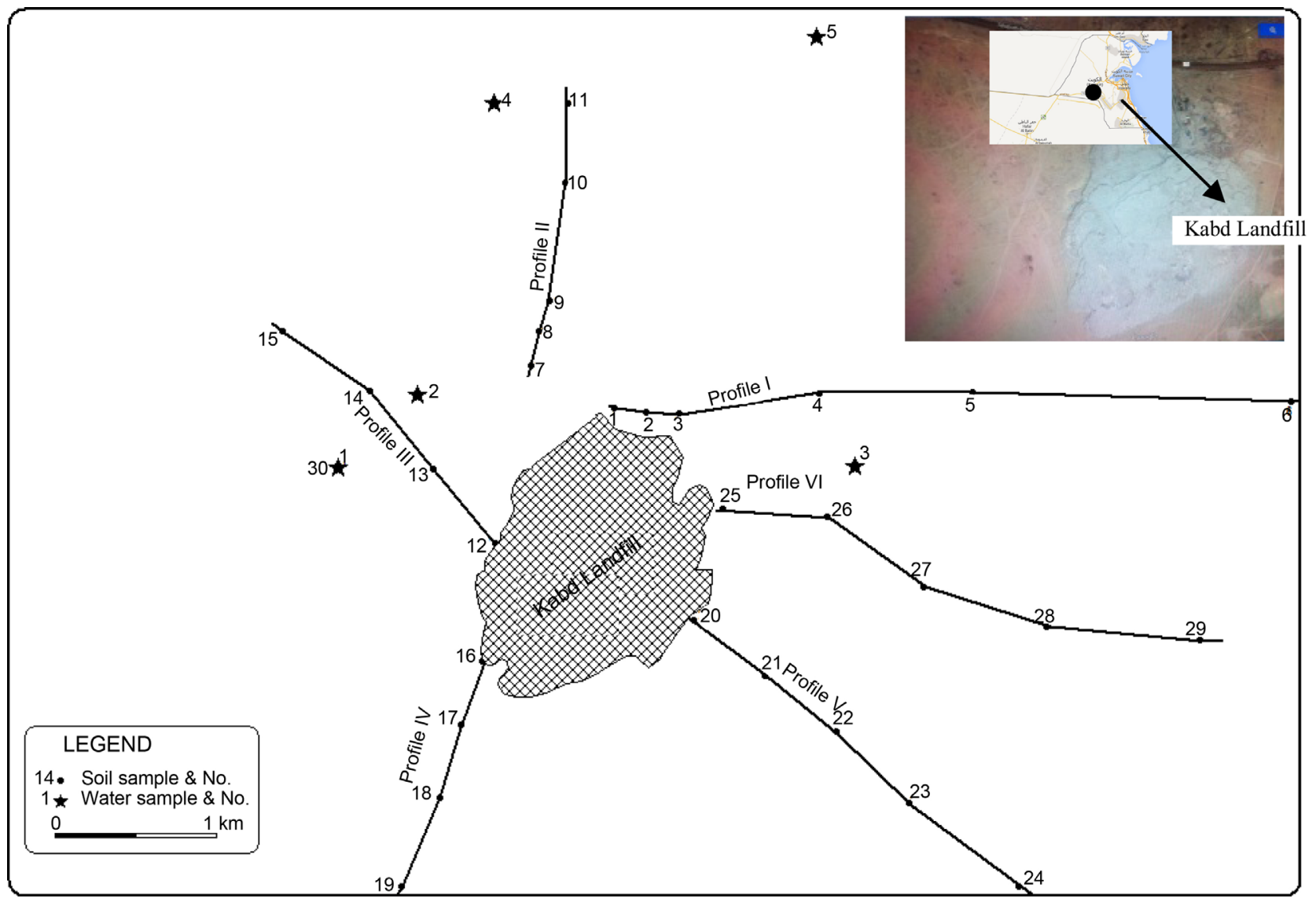

Figure 3. Sample locations of groundwatwer wells and soil samples around Kabad Landfill.

\section{Results and Discussions}

\subsection{Chemical Analyses of Groundwater}

The results of the groundwater chemical analyses are presented in Table 1. A very high variation was noted in the concentrations of the total dissolved solids (TDS) that ranged from 9820 to $12,740 \mathrm{mg} / \mathrm{L}$, with high concentrations of chloride $(\mathrm{Cl})$, sulfate $\left(\mathrm{SO}_{4}\right)$, sodium $(\mathrm{Na})$, magnesium $(\mathrm{Mg})$ and calcium $(\mathrm{Ca})$, potassium (K). The WHO and environmental quality standards (EQS) for groundwater pollution that were issued in 2013 by the Ministry of the Environment of Japan are tabulated in Table 1. The anions and cations concentrations are illustrated using the Pie and Ternary diagrams (Figure 4(a) and Figure 4(b)) that suggest saline and hard water. The Piper and Durov diagrams (Figure $4(\mathrm{c})$ and Figure $4(\mathrm{~d})$ ) identify the prominent water type in the study area that was $\mathrm{Ca}^{2+}-\mathrm{Mg}^{2+}-\mathrm{Cl}^{-}-\mathrm{SO}_{4}^{2-}$ water type.

The lateral distribution of $\mathrm{Cl}, \mathrm{SO}_{4}, \mathrm{Na}, \mathrm{Mg}, \mathrm{Ca}$ and $\mathrm{K}$ (Figure 5) reveals a tendency to increase downstream $\mathrm{N}$ and $\mathrm{NE}$ with relatively low nitrate concentrations. By contrast, Cadmium (Cd), chromium (Cr) Vanadium (V) and fluoride (F) concentrations were exceeded the standard levels of World Health Organization (WHO) and tend to decrease downstream far away from the landfill site (Figure 6). By contrast, the Nickel (Ni), Aluminum (Al), Boron (B), Lithium 
Table 1. Chemical analysis of groundwater samples (mg/L) from and around the study area.

\begin{tabular}{|c|c|c|c|c|c|c|c|}
\hline Test Parameter & Test Method & 1 & 2 & 3 & 4 & 5 & $\begin{array}{c}\text { WHO standards for } \\
\text { groundwater }\end{array}$ \\
\hline TDS & & 9820 & 10,420 & 9930 & 12,530 & 12,740 & $500 \mathrm{mg} / \mathrm{L}$ or less \\
\hline Chloride & BS1377 Part3 1990 & 3191.40 & 3468 & 4139 & 4012 & 4246 & $250 \mathrm{mg} / \mathrm{L}$ or less \\
\hline Sulfate & BS1377 Part3 1990 & 2332.00 & 2478 & 2520 & 2645 & 2670 & $400 \mathrm{mg} / \mathrm{L}$ or less \\
\hline Nitrate & BS1377 Part3 1990 & 43 & 43 & 44 & 42 & 42 & $50 \mathrm{mg} / \mathrm{L}$ or less \\
\hline Calcium & ASTM D 511 & 828.40 & 831.20 & 833.30 & 845.20 & 849.30 & $75 \mathrm{mg} / \mathrm{L}$ or less \\
\hline Magnesium & ASTM D 511 & 303.42 & 309.22 & 311.02 & 324.22 & 330.02 & $100 \mathrm{mg} / \mathrm{L}$ or less \\
\hline Sodium & Flame Photometric & 4100.00 & 4280.50 & 4290.20 & 4320.50 & 4327.20 & $35 \mathrm{mg} / \mathrm{L}$ or less \\
\hline Potassium & Flame Photometric & 32.00 & 33.00 & 33.70 & 34.40 & 36.50 & $2 \mathrm{mg} / \mathrm{L}$ or less \\
\hline Iron & ASTM D 1068 & $<0.10$ & $<0.10$ & $<0.10$ & $<0.10$ & $<0.10$ & $0.3 \mathrm{mg} / \mathrm{L}$ \\
\hline Cadmium & APHA3120 & 0.007 & 0.006 & 0.006 & 0.005 & 0.005 & $0.003 \mathrm{mg} / \mathrm{L}$ or less \\
\hline Chromium & APHA3120 & 0.539 & 0.538 & 0.536 & 0.534 & 0.530 & $0.05 \mathrm{mg} / \mathrm{L}$ or less \\
\hline Vanadium & APHA3120 & 0.36 & 0.41 & 0.40 & 0.36 & 0.33 & $40 \mathrm{mg} / \mathrm{L}$ or less \\
\hline Copper & Nano Photometric & 0.17 & 0.17 & 0.16 & 0.13 & 0.11 & $7 \mathrm{mg} / \mathrm{L}$ or less \\
\hline Nickel & Nano Photometric & 0.52 & 0.52 & 0.51 & 0.49 & 0.48 & $1.3 \mathrm{mg} / \mathrm{L}$ or less \\
\hline Zinc & Nano Photometric & 0.64 & 0.68 & 0.63 & 0.60 & 0.59 & $20 \mathrm{mg} / \mathrm{L}$ or less \\
\hline Aluminum & APHA3120 & 0.28 & 0.27 & 0.25 & 0.23 & 0.20 & $5 \mathrm{mg} / \mathrm{L}$ or less \\
\hline Lithium & APHA3120 & 0.24 & 0.24 & 0.23 & 0.21 & 0.19 & $50 \mathrm{mg} / \mathrm{L}$ or less \\
\hline Boron & APHA3120 & 0.02 & 0.02 & 0.02 & 0.01 & 0.01 & $1 \mathrm{mg} / \mathrm{L}$ or less \\
\hline Fluoride & APHA3120 & 1.1 & 1.05 & 1.09 & 0.95 & 0.90 & $0.8 \mathrm{mg} / \mathrm{L}$ or less \\
\hline
\end{tabular}

(Li), Zinc ( $\mathrm{Zn})$ and Iron $(\mathrm{Fe})$ show low levels of concentrations.

\subsection{Chemical Analyses of Soil}

The results of chemical analysis of 30 pairs of surface and subsurface soil samples are illustrated in Figure 7 and tabulated (profile-wise) with the WHO standard permissible values as shown in Table 2 .

The results indicate high concentration of heavy metals in soil samples than the WHO's standard values (Table 2). These high concentrations were recorded in both the surface and subsurface soil samples with a tendency to increase in the subsurface samples especially for $\mathrm{Ni}, \mathrm{Al}$ and $\mathrm{Fe}$.

To clarify the impact of the landfill on the groundwater contamination, particularly with heavy metals, a chart (Figure 8 ) was constructed to compare the concentration and distribution of heavy metals in the surface, subsurface soils and the groundwater.

This chart shows that the concentration of Cd (Figure 8(a)), Ni (Figure 8(b)) and Al (Figure 8(c)) were generally high and exceed in the subsurface soils samples than their surface concentrations, except the $\mathrm{Cd}$, with a tendency to increase S and SE wards far away from the landfill. The concentrations of these elements in the downstream groundwater samples shows high concentration near the landfill site and gradually decrease $\mathrm{N}$ and $\mathrm{NE}$ wads with the directions 
Table 2. Chemical analysis of soil samples (mg/kg) of the Kabd Landfill.

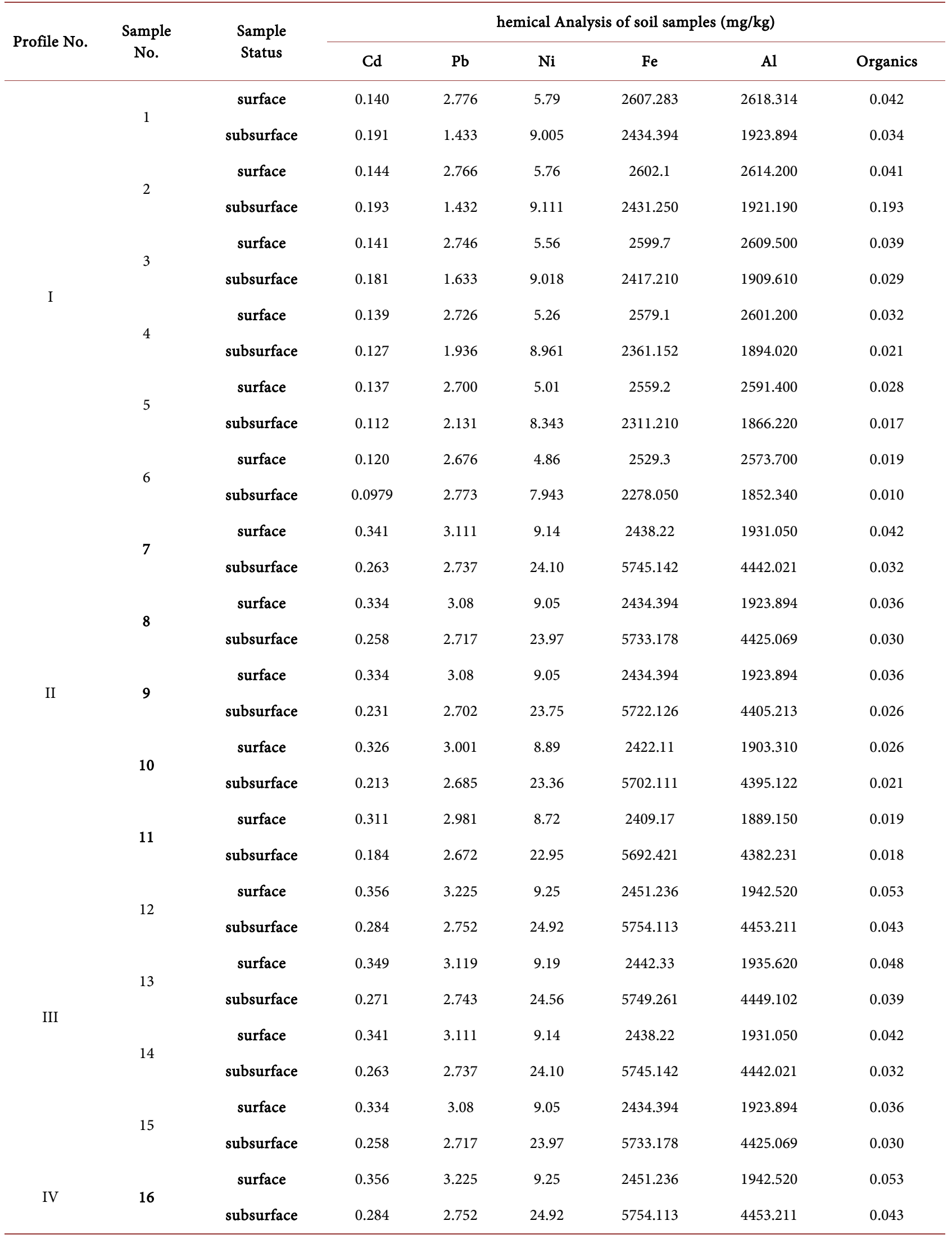




\section{Continued}

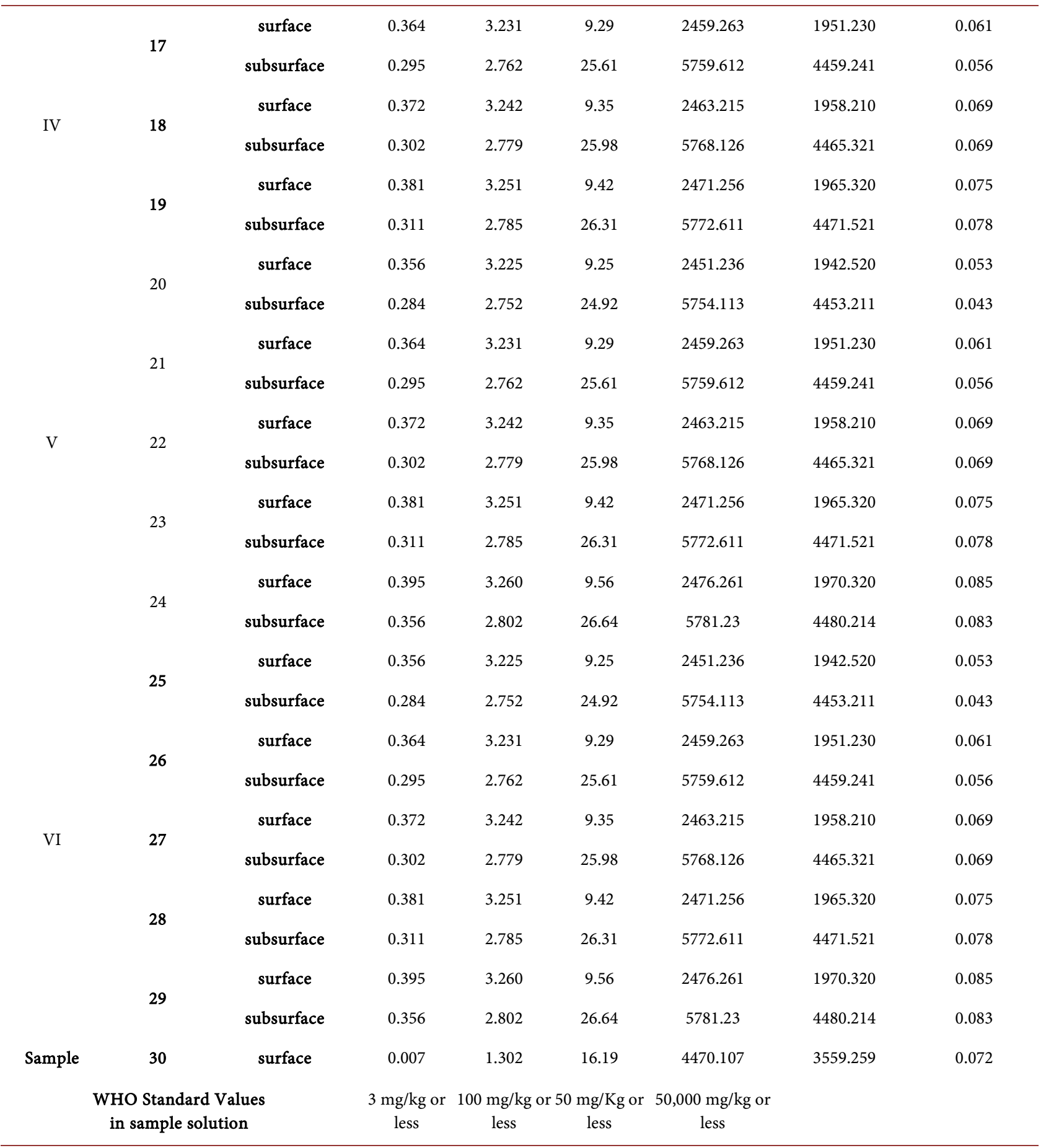

of groundwater flow. This indicates that the $\mathrm{Cd}, \mathrm{Ni}$ and $\mathrm{Al}$ contamination may be attributed to the landfill with a considerable level of confidence.

The transmission of these elements from the surface to the groundwater depends on the soil lithology, natures of dumping, the depth of quarry and the depth to the groundwater level. The major method of solid waste disposal prevailing in Kuwait is open dumping in abandoned sand quarries with an average 


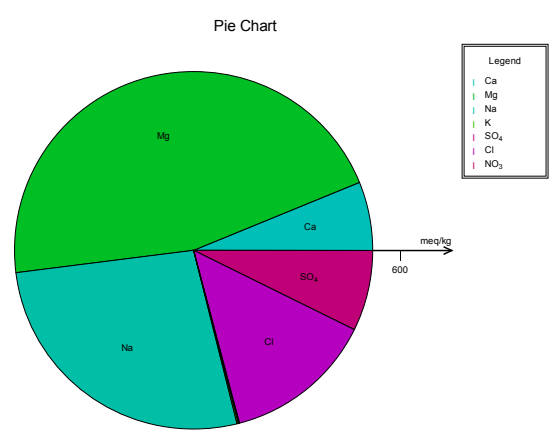

(S. No. 1)

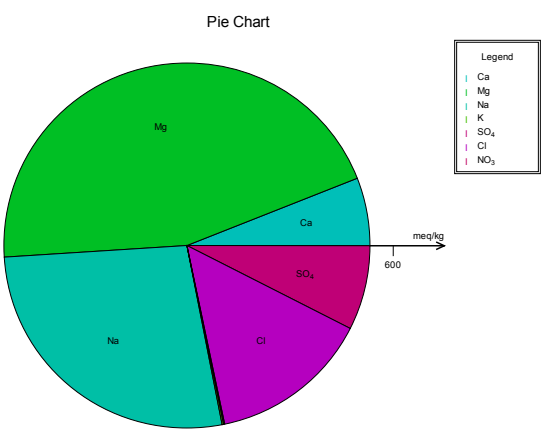

(S. No. 2)

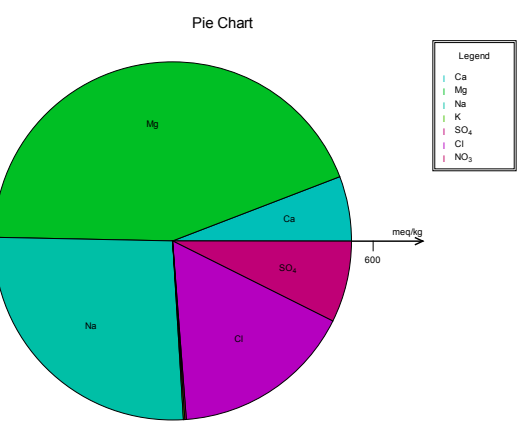

(S. No. 3)

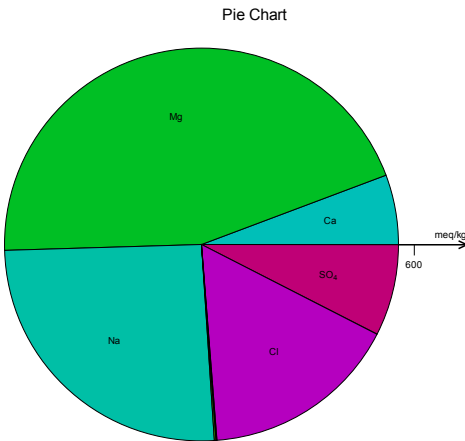

(S. No. 4)

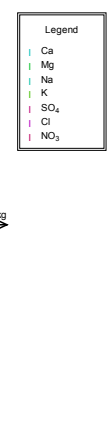

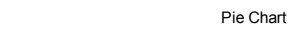

Pie Chart

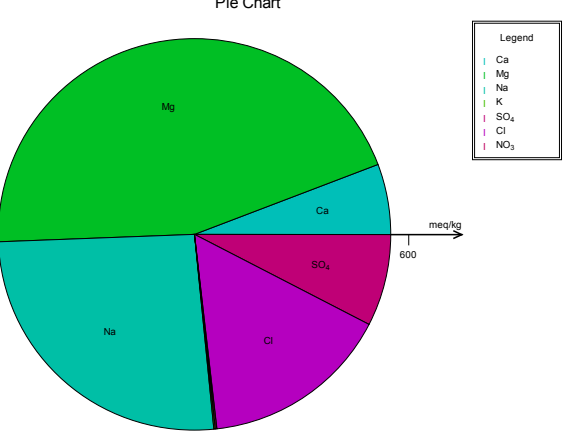

(S. No. 5)

(a)

\section{Ternary Diagram}

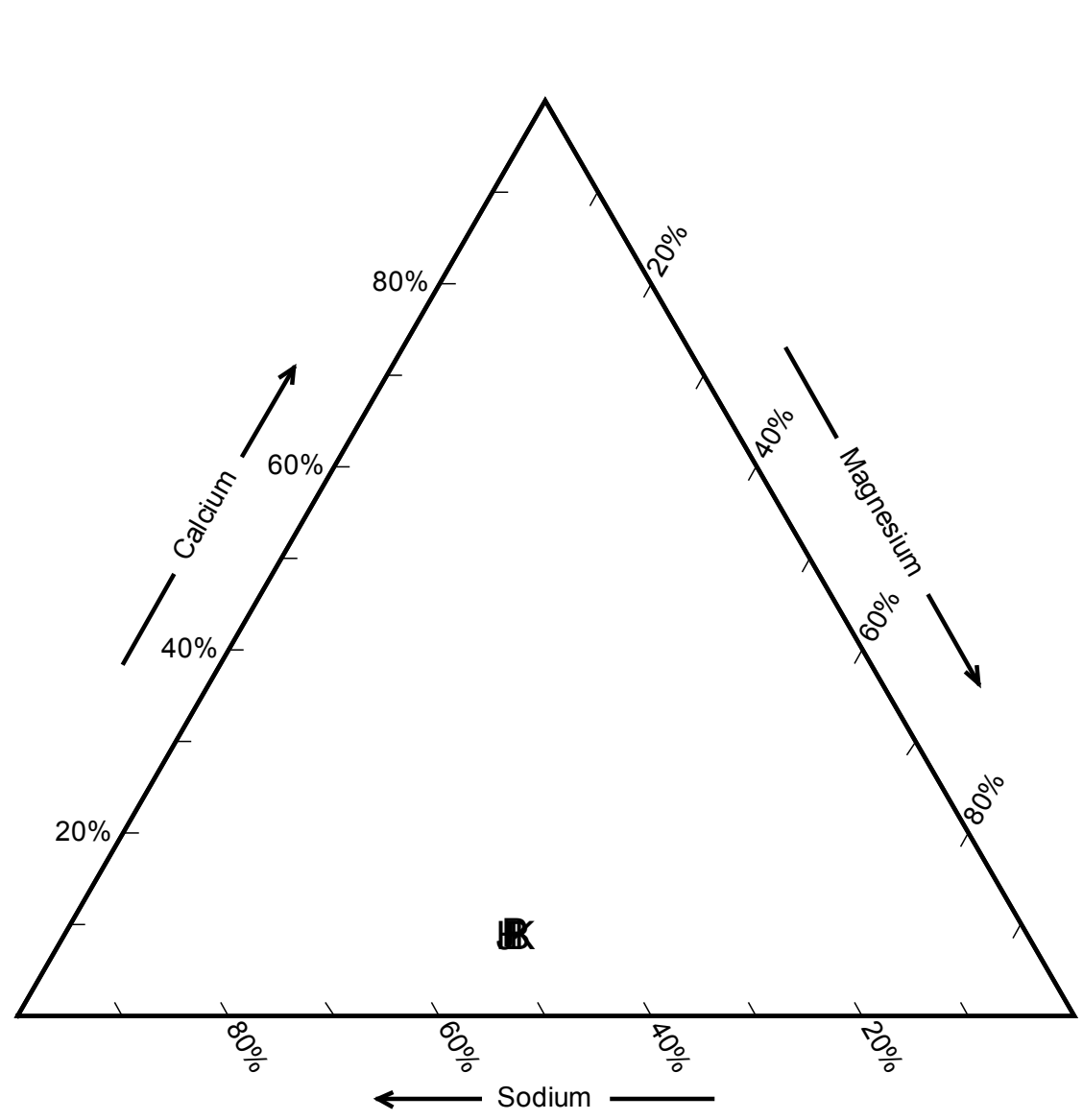

\begin{tabular}{|ll||}
\hline & Legend \\
P & 1 \\
H & 2 \\
J & 3 \\
B & 4 \\
K & 5 \\
\hline
\end{tabular}


Ternary Diagram

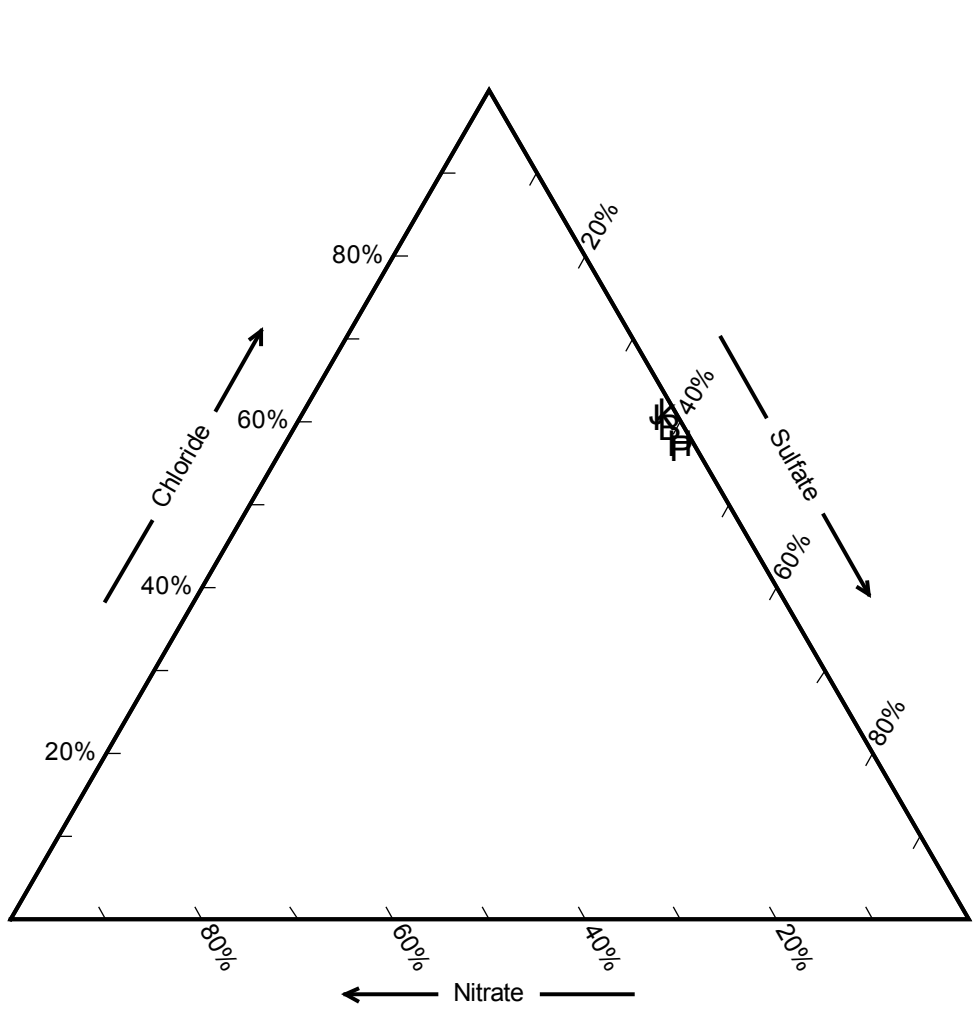

(b)

Piper Diagram



(c)
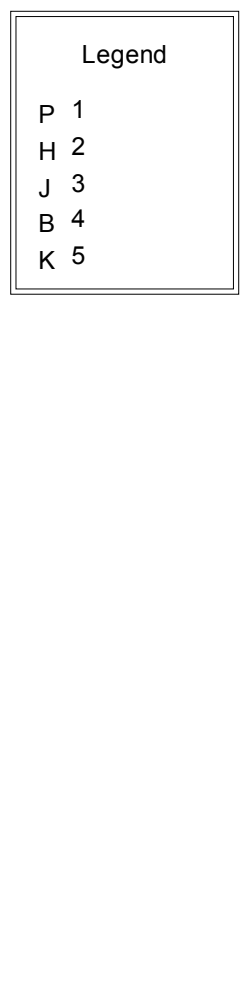

\begin{tabular}{|ll||}
\hline \multicolumn{2}{|l||}{ Legend } \\
P & 1 \\
H & 2 \\
J & 3 \\
B & 4 \\
K & 5 \\
\hline
\end{tabular}




\section{Durov Diagram}

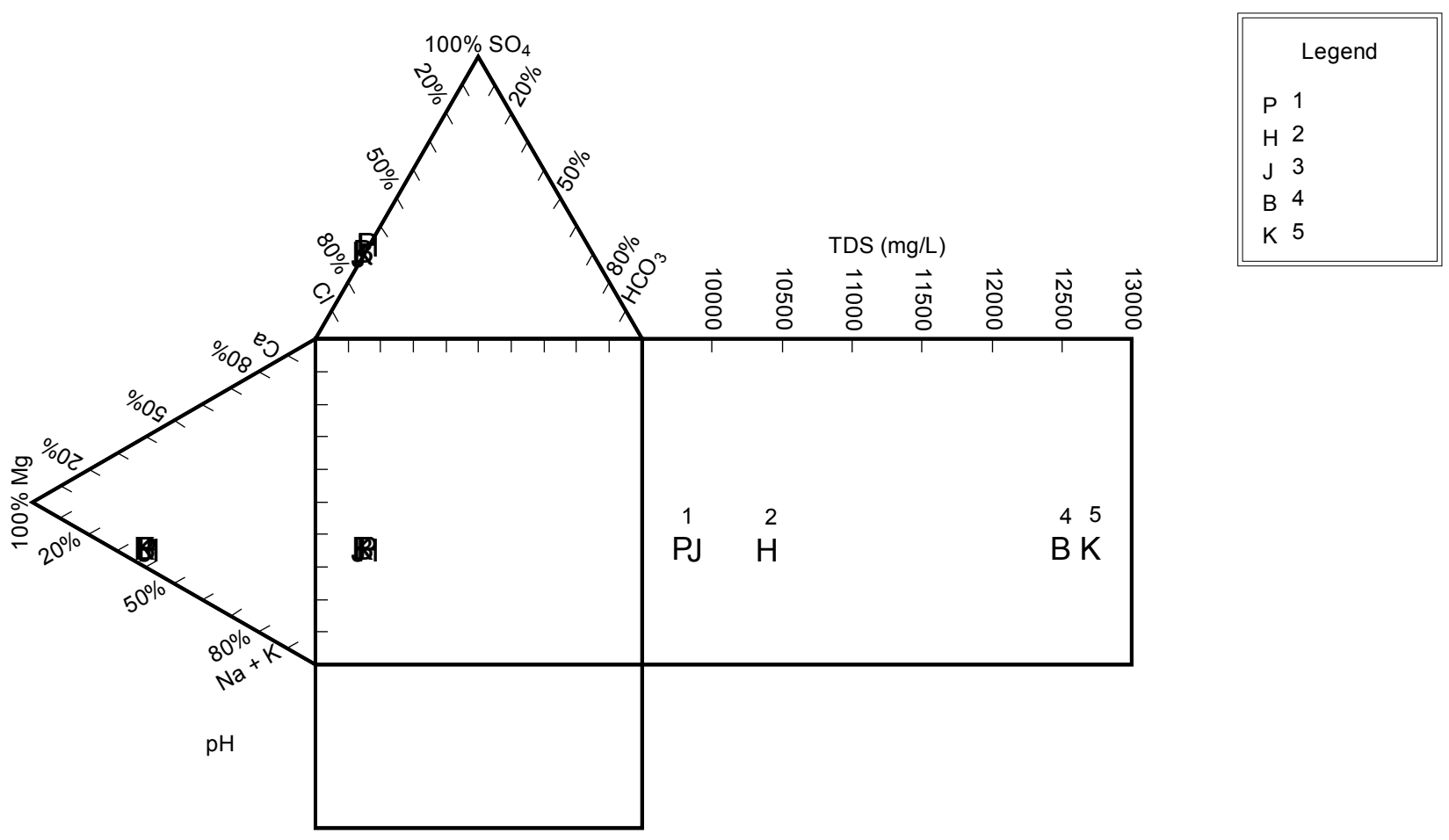

(d)

Figure 4. Pie (a), Ternary (b), Piper (c) and Durov (d) diagrams illustrate the anions and cations of the groundwater samples.

depth of $5-18 \mathrm{~m}$, then covering the waste with sand but without compaction or any protection system [8]. Therefore, contamination of the groundwater is possible due to its close level at the bottom of the waste disposal site.

On the contrary, in spite of the iron $(\mathrm{Fe})$ concentration in the surface and subsurface soil samples exhibits was high and attains the same distribution pattern in the study area (Figure 9), the Fe concentration in the groundwater samples is very low (under the detecting limit $<0.1$, Table 1 ). This reverse relationship may be attributed to the Fe dissolving habit, which depends on the amount of oxygen in the groundwater and, to a lesser extent, upon its degree of acidity [9]. Iron, for example, can occur in two forms: as $\mathrm{Fe}^{2+}$ and as $\mathrm{Fe}^{3+}$. When levels of dissolved oxygen in groundwater are greater than $1-2 \mathrm{mg} / \mathrm{L}$, iron occurs as $\mathrm{Fe}^{3+}$, while at lower dissolved oxygen levels, the iron occurs as $\mathrm{Fe}^{2+}$. Although $\mathrm{Fe}^{2+}$ is very soluble, $\mathrm{Fe}^{3+}$ will not dissolve appreciably. If the groundwater is oxygen poor, iron (and manganese) will dissolve more readily, particularly if the $\mathrm{pH}$ of the water is on the low side (slightly more acidic).

Dissolved oxygen content is typically low in deep aquifers, particularly if the aquifer contains organic matter. Decomposition of the organic matter depletes the oxygen in the water and the iron dissolves as $\mathrm{Fe}^{2+}$. Under these conditions, the dissolved iron is often accompanied by dissolved manganese or hydrogen sulfide. When this water is reached to the surface, the dissolved iron reacts with the atmospheric oxygen, changes to $\mathrm{Fe}^{3+}$ (i.e., is oxidized) and forms rust-colored 


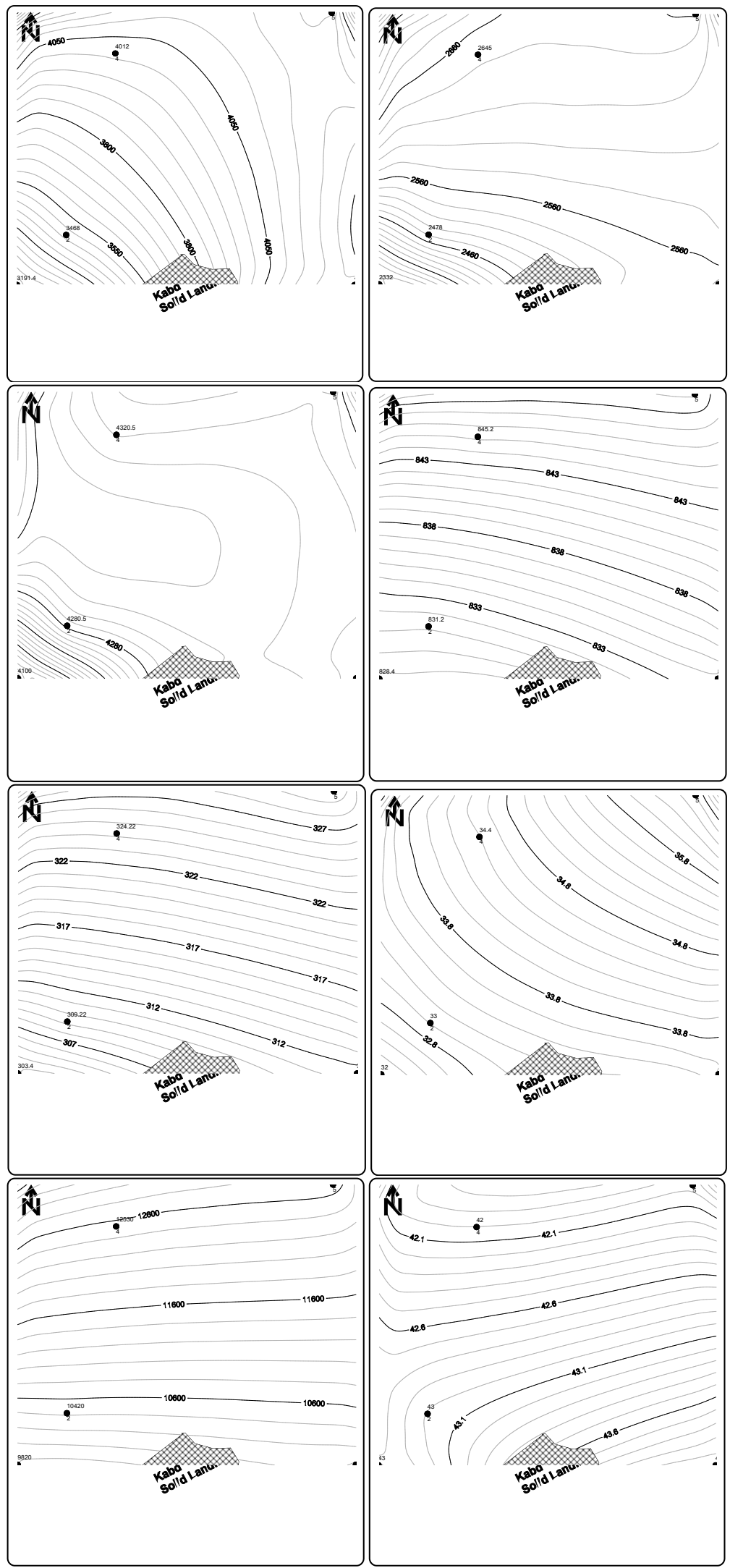

Figure 5. Contour maps show distribution of the TDS, cations and anions in the groundwater samples. 


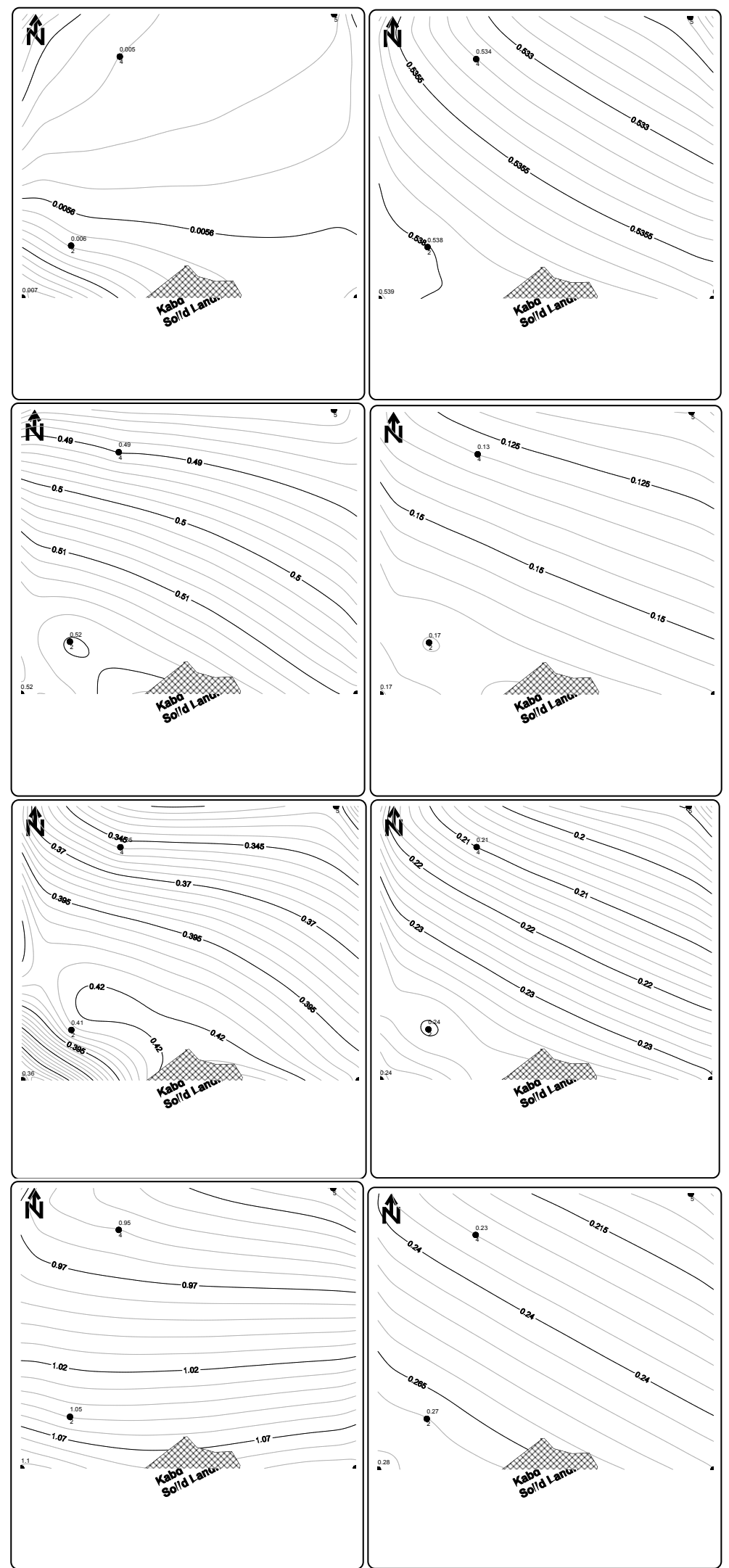

Figure 6. Contour maps show distribution of the heavy metals in the groundwater samples. 




(a)

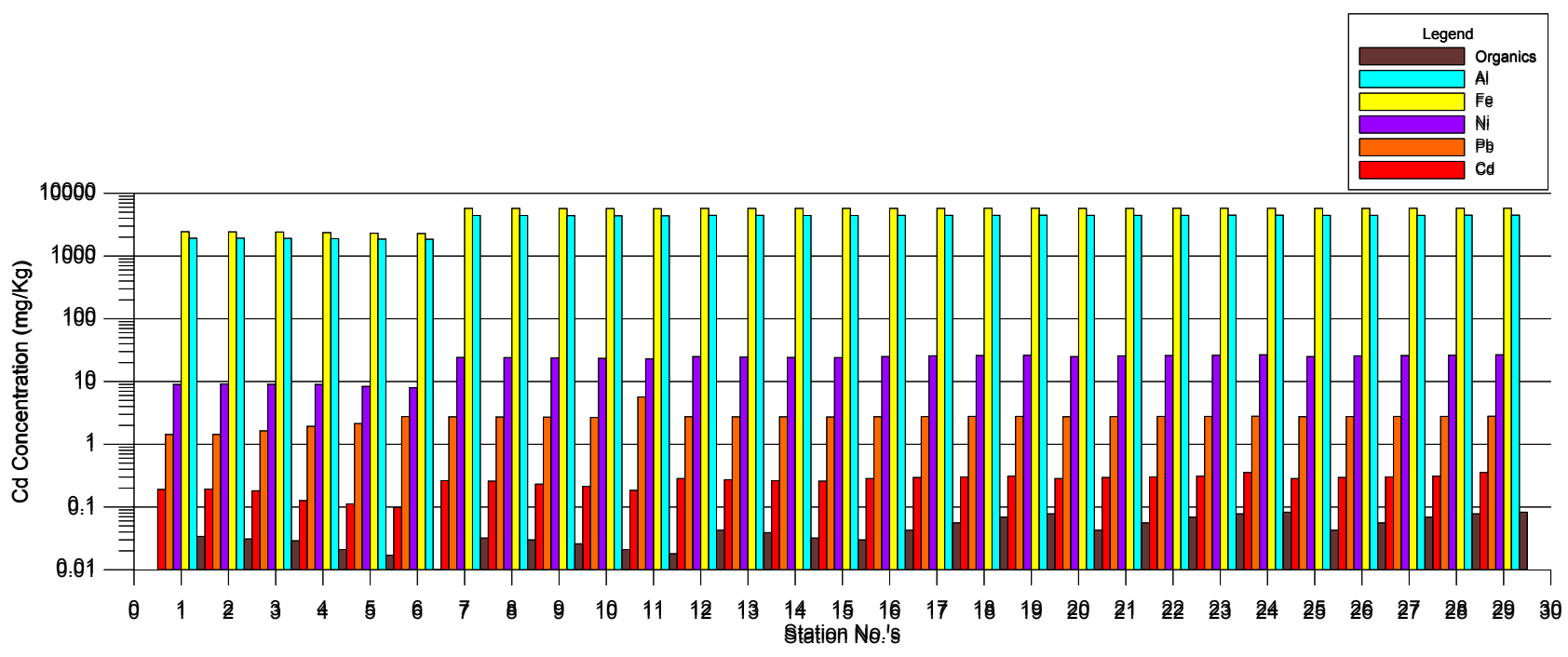

(b)

Figure 7. Heavy metal concentrations $(\mathrm{mg} / \mathrm{kg})$ in surface (a) and subsurface (b) soil samples.

iron minerals [9]. Accordingly, the amount of dissolved iron in groundwater may vary seasonally for a given well. Usually this is associated with an influx of oxygenated water from the surface during periods of high recharge. This oxygenated water will prevent the iron from dissolving and the water pumped from the well will have low concentrations of these metals. After consuming the oxygen in, iron will again be dissolved and the water will have dissolved iron characteristics.

\section{Conclusions}

The research deals with evaluation of the environmental impacts of the Kabd Landfill on the soil and groundwater. Physical and chemical analyses were carried out on five groundwater samples collected from boreholes nearby and downstream of the landfill and thirty pairs of surface and subsurface soil samples 

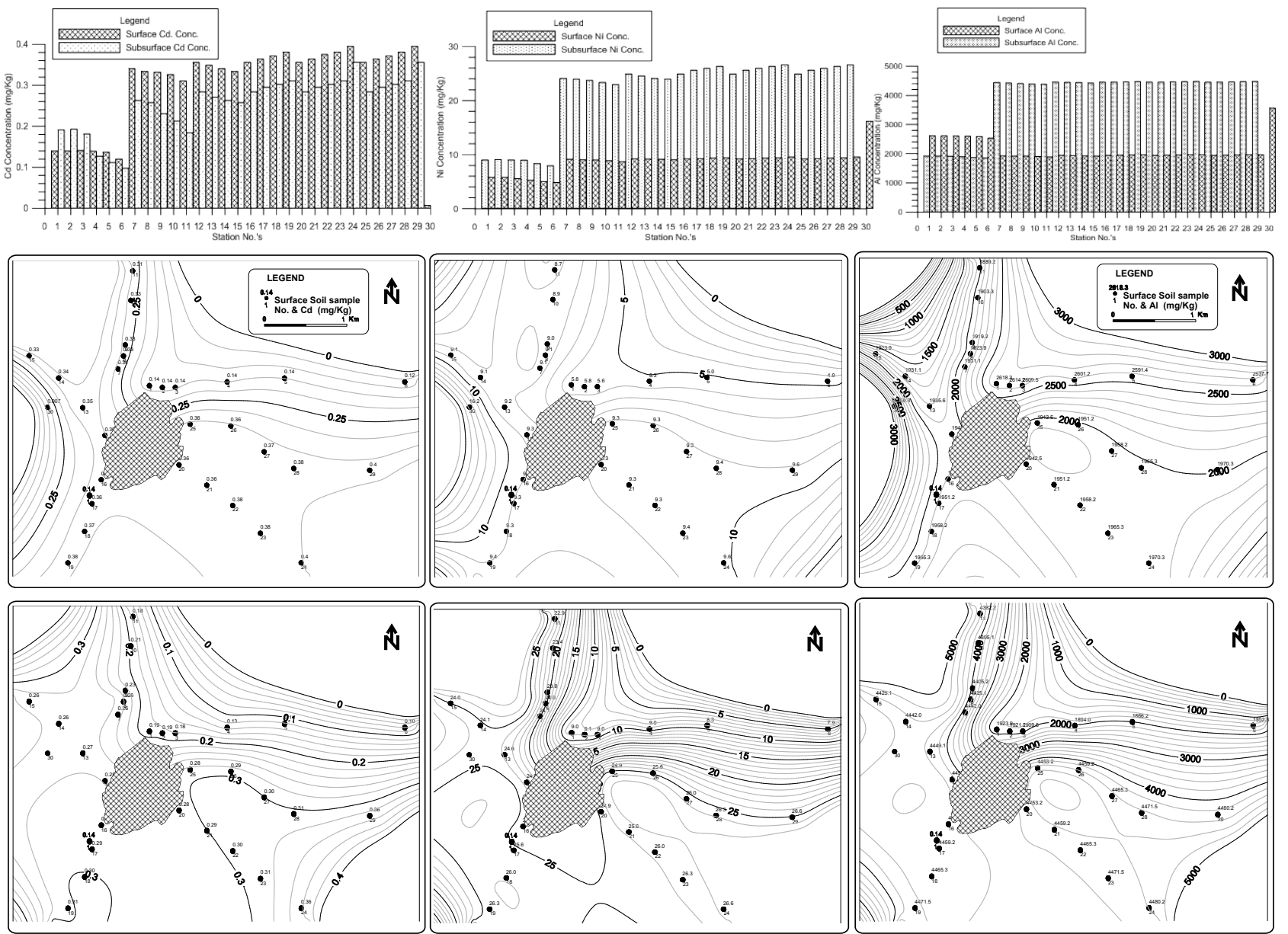

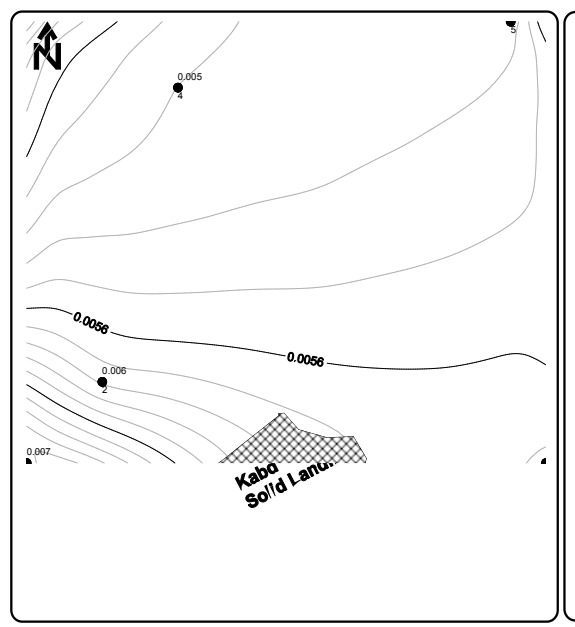

(a)

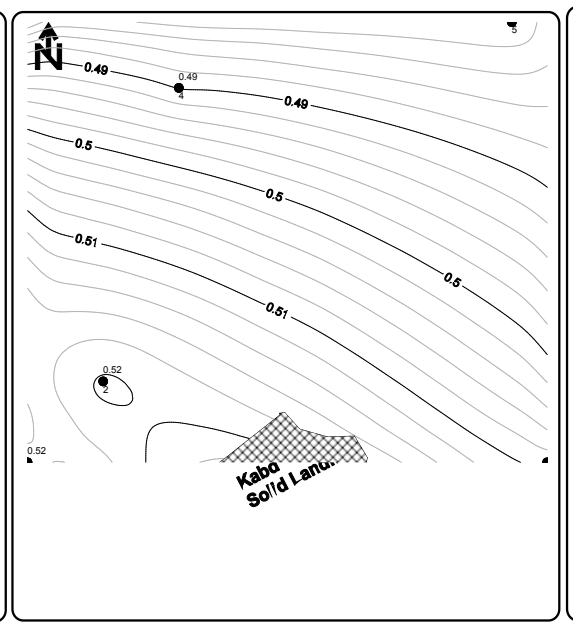

(b)

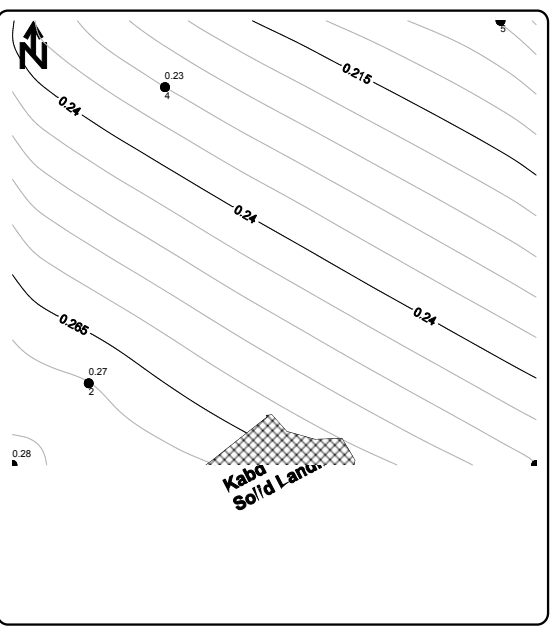

(c)

Figure 8. A chart shows comparison of $\mathrm{Cd}(\mathrm{a}), \mathrm{Ni}$ and $\mathrm{Al}$ (c) concentrations in the surface and subsurface soil samples of the Kabd Landfill area and their concentrations in the groundwater.

collected along six profiles. The groundwater samples are geochemically analyzed to determine the total dissolved solids, cations, anions and heavy metals, particularly Iron $(\mathrm{Fe})$, Copper $(\mathrm{Cu})$, zinc $(\mathrm{Zn})$, Cadmium $(\mathrm{Cd})$, Nickel $(\mathrm{Ni})$, Chromium (Cr) and Aluminum (Al), Lithium (Li), Boron (B), Fluoride (F) and 

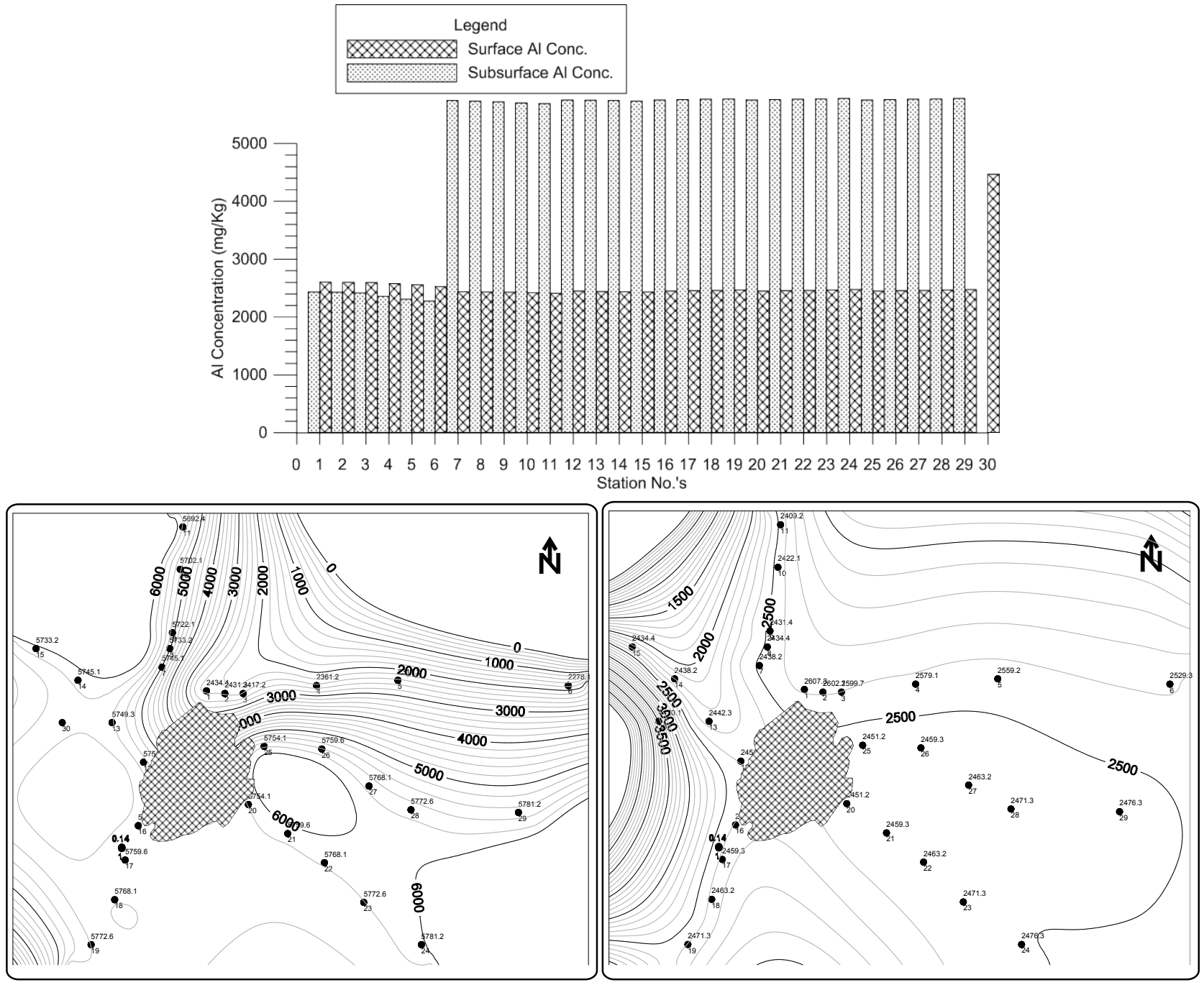

Figure 9. A comparison chart of Fe concentrations in the surface and subsurface soil samples.

Vanadium (V). The soil samples are geochemically analyzed to determine concentration of Cadmium (Cd), Lead (Pb), Nickel (Ni), Iron (Fe), Aluminum (Al).

The results are graphically illustrated and the heavy metals concentrations are compared to the WHO standard permissible limits. Such comparison shows that the soil and groundwater were contaminated with high TDS, $\mathrm{Na}, \mathrm{Ca}, \mathrm{Mg}, \mathrm{Cl}, \mathrm{SO}_{4}$ and heavy metals, especially $\mathrm{Ni}, \mathrm{Cd}, \mathrm{Cu}, \mathrm{Al}, \mathrm{V}$ and $\mathrm{F}$. The deduced $\mathrm{Zn}, \mathrm{Li}, \mathrm{B}$ and Fe metals are below the World Health Organization (WHO) limits for consumption. However, the organic strength of the soil was reduced due to waste decomposition and continuous gas flaring. The iron $(\mathrm{Fe})$ concentration shows reverse pattern of distribution, i.e. it shows very low concentrations in the groundwater samples with high concentrations in the surface and subsurface soil samples. It could be attributed to the Fe dissolving habit, which depends on the amount of oxygen in the groundwater and, to a lesser extent, upon its degree of acidity.

Interpretation of the results, in the context of the surface and subsurface geo- 
logical and hydrogeological conditions, points to the role of the soil lithology, natures of dumping, the depth of quarry and the depth to the groundwater level in leachate generation. Such leachate may be originated from the capillary fringe water, moisture content and rising water table, due to its close level at the bottom of the waste disposal site. The research is recommended that the Landfill needs modern methods of filling and/or sorting processing of the wastes components, and re-designing of sanitary landfills to prevent leachate.

\section{Acknowledgements}

The author is grateful indebted to the Research Administration Section of Public Authority for Applied Education and Training (PAAET), Kuwait for financially supporting this research under the Project number "BE-15-09". Thanks are also given to the Department of Science, college of Basic Education, for providing the facilities in the geology labs, where some analytical and experimental work was carried out.

\section{References}

[1] Aakinbile, C.O. (2012) Environmental Impact of Landfill on Groundwater Quality and Agricultural Soils in Nigeria. Soil \& Water Research, 7, 18-26. https://doi.org/10.17221/4/2011-SWR

[2] Longe, E.O. and Balogun, M.R. (2010) Groundwater Quality Assessment near a Municipal Landfill, Lagos, Nigeria. Research Journal of Applied Sciences, Engineering and Technology, 2, 39-44.

[3] Valentin, D.M., Ishee, E.R. and Ross, D. (2008) Examining Effects of a Capped Landfill on Groundwater. https://www.uvm.edu/.../Poster_Valentin-Oritz_Dorielys_2011.pdf

[4] Al Sabahi, E., Abdul Rahim, S., Wan Zuhairi, W.Y., Al Nozaily, F. and Alshaebi, F. (2009) The Characteristics of Leachate and Groundwater Pollution at Municipal Solid Waste Landfill of Ibb City, Yemen. American Journal of Environmental Sciences, 5, 256-266. https://doi.org/10.3844/ajessp.2009.256.266

[5] USEPA (2007) Municipal Solid Waste Generation, Recycling and Disposal in the United States: Facts and Figures for 2006. EPA-530-F-07-030, USEPA, Washington DC.

[6] El-Fadel, M., Findikakis, A.N. and Leckie, J.O. (1997) Environmental Impacts of Solid Waste Landfilling. Journal of Environmental Management, 50, 1-25. https://doi.org/10.1006/jema.1995.0131

[7] Muchuweti, M., Birkett, J.W., Chinyanga, E., Zvauya, R., Scrimshaw, M.D. and Lester, J.N. (2006) Heavy Metal Content of Vegetables Irrigated with Mixture of Wastewater and Sewage Sludge in Zimbabwe: Implications for Human Health. Agriculture. Ecosystem and Environment, 112, 41-48. https://doi.org/10.1016/j.agee.2005.04.028

[8] Al-Yaqout, A.F. (2003) Assessment and Analysis of Industrial Liquid Waste and Sludge Dispoal at Unlined Landfill Sites in Arid Climate. Waste Management, 23, 817-824. https://doi.org/10.1016/S0956-053X(03)00036-9

[9] Ityel, D. (2011) Ground Water: Dealing with Iron Contamination. Filtration \& Separation, 26-28. https://doi.org/10.1016/S0015-1882(11)70043-X 